Burcu Sumer Tuzun, Tugce Fafal, Pelin Tastan, Bijen Kivcak*, Besra Ozmen Yelken, Cagla Kayabasi, Sunde Yılmaz Susluer and Cumhur Gunduz

\title{
Structural characterization, antioxidant and cytotoxic effects of iron nanoparticles synthesized using Asphodelus aestivus Brot. aqueous extract
}

https://doi.org/10.1515/gps-2020-0016

Received July 09, 2019; accepted December 01, 2019.

Abstract: $A S P$ was used to synthesize $\mathrm{FeNP}_{\mathrm{A}}$. They were characterized by UV-vis spectroscopy, FT-IR, TEM, SEM, XRD and ZP. The aim of this study was to evaluate in vitro cytotoxic activity and antioxidant acitivities of $\mathrm{FeNP}_{\mathrm{A}}$ and $A S P$. The antioxidant properties were evaluated using DPPH, ABTS ${ }^{+}$and $\mathrm{H}_{2} \mathrm{O}_{2}$ assays. FeNP ${ }_{\mathrm{A}}$ had higher antioxidant activity comparing to ASP according to DPPH $\left(\mathrm{IC}_{50}\right.$ : $3.48 \mu \mathrm{g} / \mathrm{mL})$ and $\operatorname{ABTS}^{+}(60.52 \%)$ assays. Anti-cancer activities of FeNP and $A S P$ were investigated in breast cancer, melanoma and control cell lines. FeNP was more cytotoxic than ASP in MCF-7, MeWo, CHL-1, and HEL 299 cells. $\mathrm{FeNP}_{\mathrm{A}}$ had shown that mitochondria induce apoptosis through stress in MDA-MB-231, and cells MeWo. ASP also induced apoptosis 2.23-fold in MCF-7 cells. Progesterone receptor gene expression showed a 10-fold increase in a hormone-dependent MCF-7 cell line in ASP, and FeNP treatment. Expressions of BCL6, CXCL12, DNAJC15, RB1 and TPM1 in melanoma cancer cell lines were significantly increased in ASP and $\mathrm{FeNP}_{\mathrm{A}}$ administration. It had been shown that FeNP regulates gene expressions that may be considered important in terms of prognosis in breast cancer and melanoma cell lines and it is suggested that gene expressions regulated by $\mathrm{FeNP}_{\mathrm{A}}$ are also evaluated in animal models in vivo.

Keywords: Asphodelus aestivus Brot.; iron oxide nanoparticles; cancer cell line; gene

\footnotetext{
* Corresponding author: Bijen Kivcak, Department of Pharmacognosy, Faculty of Pharmacy, Ege University, Izmir, Turkey, tel.: +90 232311 2520; fax.: +90 232388 5258,

e-mail: bijen.kivcak@ege.edu.tr, bijenkivcak@gmail.com; Burcu Sumer Tuzun, Tugce Fafal and Pelin Tastan, Department of Pharmacognosy, Faculty of Pharmacy, Ege University, Izmir, Turkey Besra Ozmen Yelken, Cagla Kayabasi, Sunde Yılmaz Susluer and Cumhur Gunduz, Department of Medical Biology, Faculty of Medicine, Ege University, Izmir, Turkey
}

\author{
List of abbreviations \\ $\mathrm{FeNPa} \quad$ Iron nanoparticles \\ FeNP $_{\mathrm{A}} \quad$ Iron oxide nanoparticles of Asphodelus \\ aestivus aqueous extract \\ ASP Asphodelus aestivus aqueous extract \\ UV-vis Ultraviolet-vis spectroscopy \\ FT-IR Fourier transform infrared spectroscopy \\ TEM Transmission electron microscopy analysis \\ SEM/EDX Scanning electron miroscopy/energy disperse \\ X-ray spectroscopy \\ TGA Thermal gravimetric analysis \\ XRD X-ray diffraction analysis \\ ABTS $^{+} \quad$ 2,2'-azino-bis (3-ethyl benzo-thiazoline-6- \\ sulphonic acid) \\ DPPH 1-1-diphenyl-2-picryl-hydrazyl \\ $\mathrm{H}_{2} \mathrm{O}_{2} \quad$ Hydrogen peroxide \\ EMEM Eagle's Minimum Essential Medium \\ DMEM Dulbecco's Modified Eagle Medium \\ PI Propidium iodide \\ ROS Reactive oxygen species \\ AIF Apoptosis inducing factor \\ KRT $5 \quad$ Keratin 5 \\ IGF Insulin-like growth factor
}

\section{Introduction}

Nanotechnology allows to work scale in the $1-100 \mathrm{~nm}$ range and takes advantage of small structures for new properties and activities [1-3]. Since 1990s iron nanoparticles $\left(\mathrm{FeNP}_{\mathrm{s}}\right)$ draw much attention in nanotechnology, because of their high intrinsic reactivity of surface sites [4], biocompatibility, surface modifiability and high surface to volume ratio [5]. Iron nanoparticles can be synthesized by different chemical and physical methods such as sol-gel reactions, hydrothermal methods, polyol methods, microemulsion process, radiolysis, aerosol pyrolysis and laser pyrolysis [6]. Recently synthesizing iron oxide nanoparticles using green chemistry attract scientists because of their non toxic and eco friendly properties [7]. 
Iron oxide nanoparticles are widely used in various fields of science. Their usage in biomedical field such as anticancer, antimicrobial, larvicidial, antiplasmodial, targeted drug delivery and cancer therapy are remarkable. Besides, iron nanoparticles are used in lithium ion batteries, high performance $\mathrm{CO}$ gas sensors, biosensors and jet printing make use of iron nanoparticles [6,7]. However, in recent years the most prominent features of them are their antitumoral effects [8].

Asphodelus aestivus is a species from Liliaceae family. A. aestivus shows a wide spread in Turkey. In the previous study, our research group obtained, characterized and investigated antioxidant activity of silver nanoparticles from $A$. aestivus $[9,10]$.

Cancer is one of the most important fatal disease. It is specified as the second most common disease which causes death. Millions of people are reported to die because of cancer [11-13]. Cancer treatment has emerged as a seperate issue in recent years due to the side effects [14]. Nano-technology may take care and companse some of the problems, so scientist are trying to use less toxic and useful natural compounds in nano dimensions [15-17].

In the whole world lung, breast, colorectal, stomach and liver cancers are most common ones. Breast cancer is the most common malignancy in women and is one of the three most prevalant cancers worldwide with lung and colon cancers [18]. A variety of methods and drugs have been discovered and used for their treatment [19-21]. MDA-MB-231 and MCF-7 are breast cancer cell lines derived from mammary gland tissue derived from the pleural effusion metastatic region (ATCC, 2016). MDA-MB231 represents a basal-like subtype with a triple negative feature [22-25].

Melagnoma is caused by malignant transformation of melonocyte cells responsible for the formation of melanin pigment [26]. MeWo is a human tissue-derived melanoma cell line of the skin tissue initiated by primer culture from the lymph node of the metastatic region. CHL-1, RPMI 7932 is a human malignant melanoma cell line derived from the skin tissue created by transefection of the human melanoma cell line. While MeWo cells morphologically have displayed fibroblast structure, CHL-1 cells have showed epithelial structure (ATCC, 2016). In the present study iron oxide nanoparticles of A. aestivus were prepared and $\mathrm{FeNP}_{\mathrm{A}}$ were characterized. The aim of the present research was to evaluate the in vitro cytotoxic and antioxidant activities both $\mathrm{FeNP}_{\mathrm{A}}$ and aqueous extract of $A$. aestivus and compare the differences caused by nanoparticles.

\section{Materials and methods}

\subsection{Plant material}

A. aestivus Brot. (Asphodelaceae) was collected from Kusadasi (Aydın) on January 2014. The plant was identified by Prof. Dr. Bijen KIVCAK from Ege University Faculty of Pharmacy, Department of Pharmacognosy, Izmir, Turkey and a voucher specimen (No. 1520) is deposited in Herbarium of the Ege University, Faculty of Pharmacy.

\subsection{Preparation of the plant extract}

The aerial plant extract was prepared by infusion in the ratio of $5 \%$. It was then filtered and the filtrate was concentrated using vacuum evaporator. A. aestivus aqueous extract $(A S P)$ was obtained.

\subsection{Synthesis of FeNP}

$5 \mathrm{~mL}$ of $A$. aestivus water extract was mixed with $5 \mathrm{~mL}$ of $0.001 \mathrm{M}$ aqueous $\mathrm{FeCl}_{3}$ solution in a $1: 1$ ratio. The mixture was incubated at $50^{\circ} \mathrm{C}-60^{\circ} \mathrm{C}$ for $20 \mathrm{~min}$ with shaking. The color development, which turns black from orange, had shown the formation of iron oxide nanoparticles. The UV spectrum of Fe particles solution was drawn. Therefore, mixture centrifuged at $5000 \mathrm{rpm}$ for $30 \mathrm{~min}$. The material was then stored at $-80^{\circ} \mathrm{C}$ for $24 \mathrm{~h}$ and then lyophilized.

\subsection{Characterization of nanoparticles}

\subsubsection{Ultraviolet-vis (UV-vis) spectroscopy}

UV-vis spectra was recorded using Thermo Evalution Array UV-vis spectrophotometer (Evolution Array; Thermo Scientific, Waltham, MA, USA) in the range of 200-800 nm at room temperature. In order to carry out the experiment quartz cuvettes were used. The purpose of UV-vis spectra was to observe the formation of iron nanoparticles [7].

\subsubsection{Fourier transform infrared spectroscopy (FT-IR)}

To perform FTIR spectroscopy potassium bromide pellets were prepared for each experiment. This method was used to determine the stability and the attachment of 
biomolecules to the iron oxide ions. A Perkin-Elmer, Spectrum 100 spectrometer was used for the analysis in the range of $4000-280 \mathrm{~cm}^{-1}$ (Perkin Elmer Inc., Wellesley, MA, USA). According to FT-IR analysis of $\mathrm{FeNP}_{\mathrm{A}}$ and $A S P$, the bonds responsible from formation of iron oxide nanoparticles are detected. Among these analyses, we would determine the bonds responsible from formation of nanoparticles by comparison FT-IR results.

\subsubsection{Transmission electron microscopy analysis (TEM)}

Transmission electron microscopy (TEM) analysis was performed to get a priliminary idea about particle size and take a microscope image of nanoparticles [29]. The $\mathrm{FeNP}_{\mathrm{A}}$ images were taken by a Libra 120 transmission electron microscope (Carl Zeiss, Oberkochen, Germany). Electronic radiation was used to take images and it detects the electrons transported through the sample. $80-120 \mathrm{kV}$ accelaration volt and in column OMEGA filter was used for the device.

\subsubsection{Scanning electron microscopy/energy-dispersive $X$-ray spectroscopy (SEM/EDX)}

This characterization method shows the size and shape of the nanoparticles. The morphology was determined by SEM. A SEM 250 FEG Quanta instrument was used for the determination. SEM 250 FEG Quanta instrument was used with an EDX detector (Oxford Azteck) to identify the composition of nanoparticles.

\subsubsection{Thermal gravimetric analysis (TGA)}

TGA experiments indicated the thermal stability of iron oxide nanoparticles [30]. A Perkin-Elmer Diamond TG/DTA (Thermogravimetric and Differential Thermal Analysis) was used for the experiments. Device was operated with a heating rate of $20^{\circ} \mathrm{C} / \mathrm{min}$ and achiewed between $20^{\circ} \mathrm{C}-500^{\circ} \mathrm{C}$ temperature rate.

\subsubsection{X-ray diffraction analysis (XRD)}

The analyses were done at room temperature by the device Rigaku Ultima IV X-ray diffractometer (Rigaku Corp., Tokyo, Japan) to examine the differactions of nanoparticles. The device was operated at a voltage of $45 \mathrm{kV}$ and copper potassium alpha radiation ( $40 \mathrm{~mA})$ was used.

\subsubsection{Particle size distribution and zeta potential}

Nano-zs Zetasizer (Zetasizer-Nano-ZS, Malvern, UK) was used for particle size distribution and zeta potential. Particle size distribution and zeta potential are important to understand the homogeneity, stability and functionality of particles. High zeta potential shows how stable nanoparticle is [5]. Samples were diluted in distilled water. Particle size distribution and polydispersity index were examined at room temperature. A polydispersity index higher than 0.5 showed that the formation was not homogenous. Zeta potential was also evaluated at room $25^{\circ} \mathrm{C}$ using the angle $17^{\circ}$, with 78.5 dielectric constant. Electrical field was operated to $15 \mathrm{v} / \mathrm{cm}$.

\subsection{Determination of antioxidant activities}

\subsubsection{2,2'-azino-bis(3-ethylbenzothiazoline-6-sulphonic acid) $\left(\right.$ ABTS $\left.^{+}\right)$assay}

$\mathrm{FeNP}_{\mathrm{A}}$ and $A S P$ were determined for their ABTS cation radical scavenging activity. $245 \mathrm{mM}$ potassium persulphate solution and $7 \mathrm{mM}$ ABTS were mixed. The mixture was incubated for $16 \mathrm{~h}$. After incubation the solution was diluted until the absorbance at $743 \mathrm{~nm}$ becomes 0.7 . The prepared solution and $100 \mu \mathrm{L}$ sample were stirred and incubated at room temperature for $6 \mathrm{~min}$. The absorbance was measured at $734 \mathrm{~nm}$ using UNIQCAM $8625 \mathrm{UV} /$ Vis spectrophotometer [31]. Ethanol was used as blank whereas $\alpha$-tocopherol was used as a standard.

\subsubsection{1-1-diphenyl-2-picryl-hydrazyl (DPPH) radical scavenging assay}

The free radical scavenging activity was determined using the 1-1-diphenyl-2-picryl-hydrazyl (DPPH) $0.1 \mathrm{~mL}$ of $0.1 \mathrm{mM}$ solution of DPPH was added to $3 \mathrm{~mL}$ of $A S P$ and $\mathrm{FeNP}_{\mathrm{A}}$ of differentconcentration. The mixture was incubated at room temperature for $30 \mathrm{~min}$ and absorbance was measured at $517 \mathrm{~nm}$ using UNIQCAM $8625 \mathrm{UV} /$ Vis spectrophotometer [31]. The percentages of scavenging activity values was calculated using the following formula:

$$
\text { Percentage of scavenging }=\left(A_{0}-A_{1}\right) / A_{0} \times 100
$$

where:

$A_{0}=$ Absorbance of control

$A_{1}=$ Absorbance of sample.

$\alpha$-Tocopherol was used as a positive control. 


\subsubsection{Hydrogen peroxide scavenging assay $\left(\mathrm{H}_{2} \mathrm{O}_{2}\right)$}

0.1 M, pH 7.4 phosophate buffered saline was added in hydrogen peroxide $(40 \mathrm{mM})$ solution. $600 \mu \mathrm{L}$ of hydrogen peroxide solution and $1 \mathrm{~mL}$ of the $A S P$ and $\mathrm{FeNP}_{\mathrm{A}}$ containing samples of different concentration were rapidly mixed. The mixture was incubated at room temperature for $10 \mathrm{~min}$. The absorbance was measured at $230 \mathrm{~nm}$ by UNIQCAM $8625 \mathrm{UV} /$ Vis spectrophotometer against a blank (without hydrogen peroxide). The percentage of scavenging of hydrogen peroxide was calculated using the following formula. Quercetin was used as a positive control [32].

$$
\text { Percentage scavenging }\left(\mathrm{H}_{2} \mathrm{O}_{2}\right)=\left(\mathrm{A}_{0}-\mathrm{A}_{1}\right) / \mathrm{A}_{0} \times 100
$$

where:

$\mathrm{A}_{0}=$ Absorbance of control

$\mathrm{A}_{1}=$ Absorbance of sample

\subsection{Cell lines}

Cancer cell models were selected as breast cancer models MCF-7 and MDA-MB-231 and melanoma cancer models MeWo and CHL-1 and fibroblast cell models WI-38 and HEL 299 (control cell models). Cell lines were cultured and maintained in mediums (EMEM for MCF-7, MeWo, HEL-299, WI-38 cell lines, DMEM for CHL-1 cell line and L15 for MDAMB-231 cell line) containing 1\% L-glutamine supplemented with 10\% inactivated FBS and 1\% penicillin/streptomycin and were maintained in a humidified incubator at $37^{\circ} \mathrm{C}$ with $5 \% \mathrm{CO}_{2}$. Analysis of cell viability was carried with trypan blue test.

\subsection{Cytotoxicity assay}

To determine the cytotoxic effect of $\mathrm{FeNP}_{\mathrm{A}}$ and $A S P$ on the MCF-7, MDA-MB-231, MeWo, CHL-1, WI-38 ve HEL 299 cell lines, cells were seeded in 96-well E-plate and treated with variable concentrations (3.13-100.00 $\mu \mathrm{g} / \mathrm{mL}$ ) of $\mathrm{FeNP}_{\mathrm{A}}$ and $A S P$. Cytotoxicity activity was achieved by normalize cell index using xCELLIGENCE software and $\mathrm{IC}_{50}$ values and analysis were determined by sigmoidal dose-response analysis.

\subsection{Analysis of apoptosis}

Apoptotic effects of the $A S P$ and $\mathrm{FeNP}_{\mathrm{A}}$ on the cells were evaluated by AnnexinV-EGFP Apoptosis Detection Kit
Biovision. Initially, $5 \times 10^{5}$ cells were treated with their IC50 doses of each for $72 \mathrm{~h} .72 \mathrm{~h}$ later, cells were collected. Then washed and resuspended. AnnexinV-EGFP and propidium iodide (PI) were added, and the cells were incubated. After incubation, cells were examined by flow cytometry named BD Accuri C6 Flow Cytometer.

\subsection{Gene expression analyzes}

In breast cancer and melanoma cell models, effects of the $\mathrm{FeNP}_{\mathrm{A}}$ and $A S P$ on gene expressions were assessed by real time online RT-PCR (LightCycler 480 II) by using $\mathrm{RT}^{2}$ Profiler PCR Array Human Breast Cancer (Table 2) and Human Melanoma (Table 3) PCR Array, Qiagen Kits. Total RNA extraction and cDNA were performed according to the kit manual, by using RNeasy Mini Kit (Qiagen) and RT2 First Strand Kit cDNA Synthesis kit (Qiagen), respectively.

\section{Results and discussion}

Green synthesized $\mathrm{FeNP}_{\mathrm{A}}$ had been characterized by various methods. These methods are: ultraviolet-vis (UV-vis) spectroscopy, Fourier transform infrared spectroscopy (FT-IR), transmission electron microscopy analysis (TEM), scanning electron microscopy/energydispersive X-ray spectroscopy (SEM/EDX), thermal gravimetric analysis (TGA), X-ray diffraction analysis (XRD) and particle size distribution and zeta potential.

Basically, the characteristic color change during process from yellow to reddish brown showed the formation of $\mathrm{FeNP}_{\mathrm{A}}$. In the next step UV spectrums for $\mathrm{FeNP}_{\mathrm{A}}$ and $A S P$ were evaluated [33]. After the color change a peak occured at $250 \mathrm{~nm}$ and $450 \mathrm{~nm}$ which proves iron oxide nanoparticles presence (Figure 1) [30,34,35]. The FTIR spectrum was performed by A Perkin-Elmer Spectrum 100 Spectrometer. ASP and $\mathrm{FeNP}_{\mathrm{A}}$ spectrums were compared in Figure 2. ASP spectrum gave absorbance bands at $3397 \mathrm{~cm}^{-1}, 2917.24 \mathrm{~cm}^{-1}, 1618.74 \mathrm{~cm}^{-1}, 1384.47 \mathrm{~cm}^{-1}$, $1076.66 \mathrm{~cm}^{-1}$ and $824.97 \mathrm{~cm}^{-1}$. Subsequent to formation

Table 1: Determination of antioxidant activity, total phenolic and flavonoid content of $\mathrm{FeNP}_{\mathrm{A}}$ and $A S P$.

\begin{tabular}{|c|c|c|c|}
\hline & $\begin{array}{c}\mathrm{DPPH}\left(\mathrm{IC}_{50}\right) \\
(\mu \mathrm{g} / \mathrm{mL})\end{array}$ & $\begin{array}{c}\text { ABTS }^{+}(\%) \\
(\mu \mathrm{g} / \mathrm{mL})\end{array}$ & $\begin{array}{l}\mathrm{H}_{2} \mathrm{O}_{2}(\%) \\
(\mu \mathrm{g} / \mathrm{mL})\end{array}$ \\
\hline$A S P$ & $31.65 \pm 0.01^{\mathrm{a}}$ & $39.62 \pm 0.02$ & $55.86 \pm 0.14$ \\
\hline $\mathrm{FeNP}_{\mathrm{A}}$ & $3.48 \pm 0.01$ & $60.52 \pm 0.01$ & $16.83 \pm 0.06$ \\
\hline
\end{tabular}

${ }^{a}$ Results are mean $\pm S D$ of three replicate analysis 
Table 2: “PCR Array Human Breast Cancer" 96-well microplate gene design.

\begin{tabular}{lccccccccccc}
\hline ABCB1 & ABCG2 & ADAM23 & AKT1 & APC & AR & ATM & BAD & BCL2 & BIRC5 & BRCA1 & BRCA2 \\
A01 & A02 & A03 & A04 & A05 & A06 & A07 & A08 & A09 & A10 & A11 & A12 \\
CCNA1 & CCND1 & CCND2 & CCNE1 & CDH1 & CDH13 & CDK2 & CDKN1A & CDKN1C & CDKN2A & CSF1 & CST6 \\
B01 & B02 & B03 & B04 & B05 & B06 & B07 & B08 & B09 & B10 & B11 & B12 \\
CTNNB1 & CTSD & EGF & EGFR & ERBB2 & ESR1 & ESR2 & FOXA1 & GATA3 & GL1 & GRB7 & GSTP1 \\
C01 & C02 & C03 & C04 & C05 & C06 & C07 & C08 & C09 & C10 & C11 & C12 \\
HIC1 & ID1 & IGF1 & IGF1R & IGFBP3 & IL6 & JUN & KRT18 & KRT19 & KRT5 & KRT8 & MAPK1 \\
D01 & D02 & D03 & D04 & D05 & D06 & D07 & D08 & D09 & D10 & D11 & D12 \\
MAPK3 & MAPK8 & MGMT & MK167 & MLH1 & MMP2 & MMP9 & MUC1 & MYC & NME1 & NOTCH1 & NR3C1 \\
E01 & E02 & E03 & E04 & E05 & E06 & E07 & E08 & E09 & E10 & E11 & E12 \\
PGR & PLAU & PRDM2 & PTEN & PTGS2 & PYCARD & RARB & RASSF1 & RB1 & SERPINE1 & SFN & SFRP1 \\
F01 & F02 & F03 & F04 & F05 & F06 & F07 & F08 & F09 & F10 & F11 & F12 \\
SLC39A6 & SLIT2 & SNAI2 & SRC & TFF3 & TGFB1 & THBS1 & TP53 & TP73 & TWIST1 & VEGFA & XBP1 \\
G01 & G02 & G03 & G04 & G05 & G06 & G07 & G08 & G09 & G10 & G11 & G12 \\
ACTB & B2M & GAPDH & HPRT1 & RPLP0 & HGDC & RTC & RTC & RTC & PPC & PPC & PPC \\
H01 & H02 & H03 & H04 & H05 & H06 & H07 & H08 & H09 & H10 & H11 & H12 \\
\hline
\end{tabular}

Table 3: Melanoma PCR Array 48 well microplate gene design.

\begin{tabular}{lccccc}
\hline ADAMTS18 & CLEC3B & LRP2 & NRP1 & RB1 & HPRT1 \\
A01 & A02 & A03 & A04 & A05 & A06 \\
AKAP12 & CXCL12 & LRRC2 & PCNA & S0CS2 & ACTB \\
B01 & B02 & B03 & B04 & B05 & B06 \\
ARPC2 & DNAC15 & MME & PPP1R3C & S0CS3 & GAPDH \\
C01 & C02 & C03 & C04 & C05 & C06 \\
BCL6 & DPP4 & MMP1 & PPP2R4 & THBD & B2M \\
D01 & D02 & D03 & D04 & D05 & D06 \\
BIRC5 & ENC1 & MMP12 & PRDX2 & TNFRSF10A & HGDC \\
E01 & E02 & E03 & E04 & E05 & E06 \\
BRAF & GDF15 & MMP14 & PTEN & TP53INP1 & RTC \\
F01 & F02 & F03 & F04 & F05 & F06 \\
CDH3 & IRF8 & MMP2 & QPCT & TPM1 & RTC \\
G01 & G02 & G03 & G04 & G05 & G06 \\
CDH8 & LAMC2 & MMP9 & RASEF & RPL13A & PPC \\
H01 & H02 & H03 & H04 & H05 & H06 \\
\hline
\end{tabular}

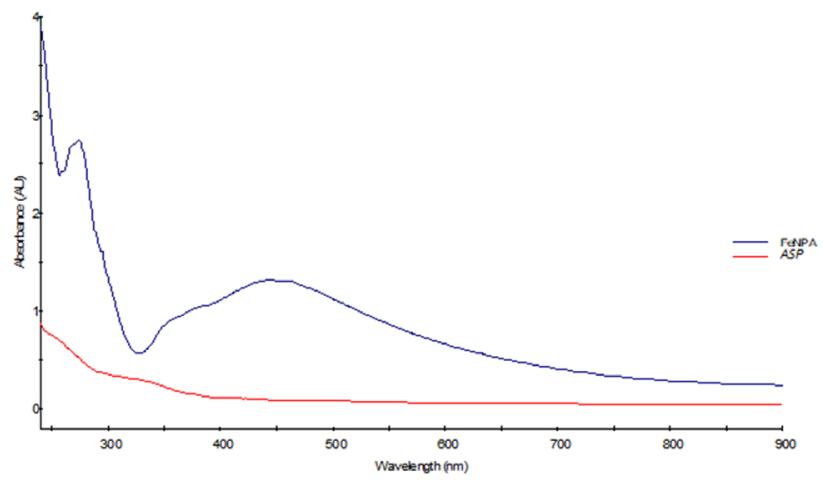

Figure 1: UV-visible spectra of the iron nanoparticles synthesized from Asphodelus aestivus extract and the aqueous extract of Asphodelus aestivus (FeNP $\mathrm{A}_{\mathrm{A}}$ :Fe nanoparticles prepared by Asphodelus aestivus aqueous extract; ASP: the aqueous extract of the aerial part of Asphodelus aestivus).

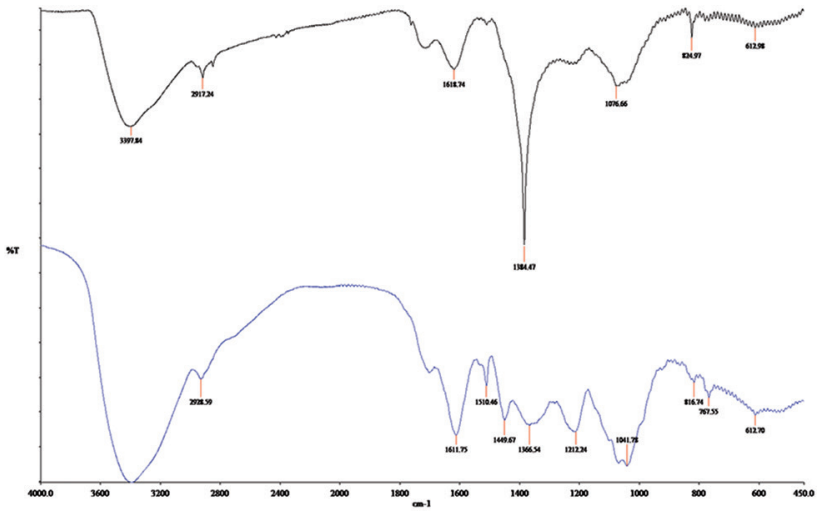

Figure 2: FT-IR spectra of $A$. aestivus aqueous extract (ASP) and FeNP $_{\mathrm{A}}$ synthesized from $A S P$.

spectrum had changed and shifts occured. The absorbance band at $1618.74 \mathrm{~cm}^{-1}$ which is responsible from $\mathrm{C}=\mathrm{C}$ aromatic chain streching vibration of phenolic compounds shifted to $1611.75 \mathrm{~cm}^{-1}$. The bending vibration of phenols of $-\mathrm{OH}$ which gave band at $1384.47 \mathrm{~cm}^{-1}$ shifted to $1366.54 \mathrm{~cm}^{-1}$. C $-\mathrm{O}$ or $\mathrm{C}=\mathrm{O}$ streching vibration formed by polysachharides which gave band at $1076.66 \mathrm{~cm}^{-1}$ shifted to $1041.78 \mathrm{~cm}^{-1}$. All of these shifts were due to a new formation: FeNP$_{\mathrm{A}}$. In addition to the shifts new absorption bands around 1000-1400 $\mathrm{cm}^{-1}\left(1449.67 \mathrm{~cm}^{-1}\right.$, $1212.24 \mathrm{~cm}^{-1}, 1041.78 \mathrm{~cm}^{-1}$ ) occured because of $\mathrm{C}=\mathrm{C}, \mathrm{OH}$, $\mathrm{C}-\mathrm{O}, \mathrm{C}=\mathrm{O}$ or $\mathrm{C}-\mathrm{O}$ streching vibration [36]. One of the most important band was at $612.98 \mathrm{~cm}^{-1}$ occured beacuse of the $\mathrm{Fe}-\mathrm{O}$ streching proved $\mathrm{FeNP}_{\mathrm{A}}$ transformation from ASP. [37]. In the next step TEM analysis was evaluated. TEM analysis provided information about general morphology. According to results, the particle size of $\mathrm{FeNP}_{\mathrm{A}}$ were about 20-25 $\mathrm{nm}$ (Figure 3). In order to acquire 
more detailed information about morphology, surface properties and elemental composition SEM/EDX analysis were used. Results indicated FeNP $\mathrm{A}_{\mathrm{A}}$ had rough surfaces. They were cavity like structures as shown in Figure 4. As it was occured in Figure 5 analysis confirmed the presence of Fe and $\mathrm{O}$ [7]. An other characterization method TGA analysis was presented in Figure 6. The initial weight loss till $193^{\circ} \mathrm{C}$ was due to removal of moisture. Second step between $193.12^{\circ} \mathrm{C}-383.26^{\circ} \mathrm{C}$ may due to combustion of organic consituents, elimination of carbon groups. Last weight loss was because of the crystal structure of

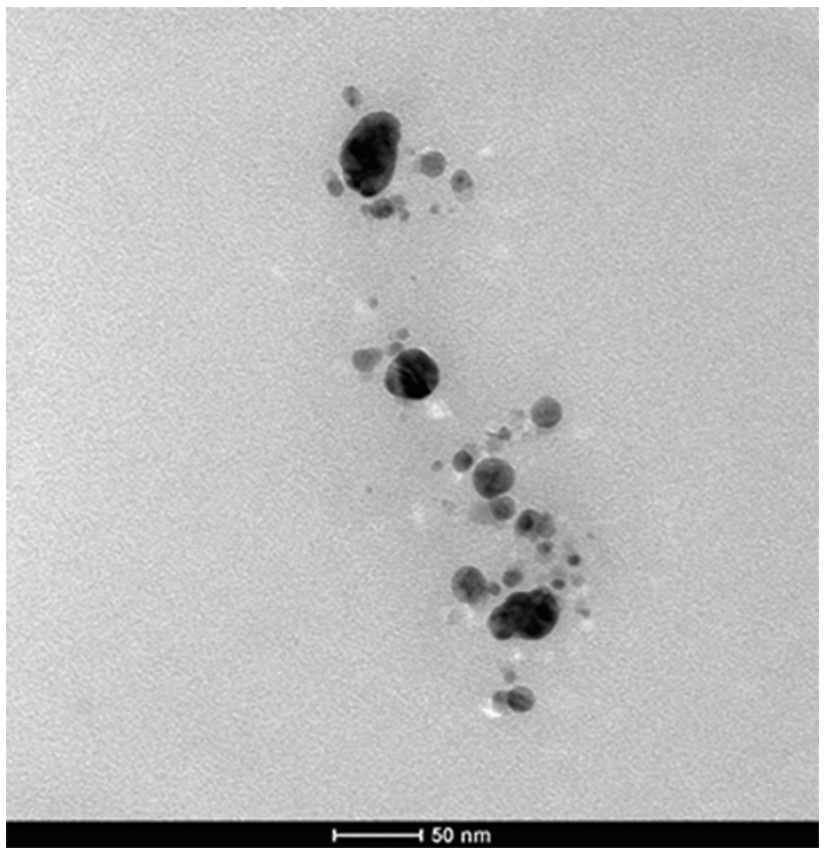

Figure 3: Transmission electron microscopy (TEM) images of FeNP synthesized by $A S P$.

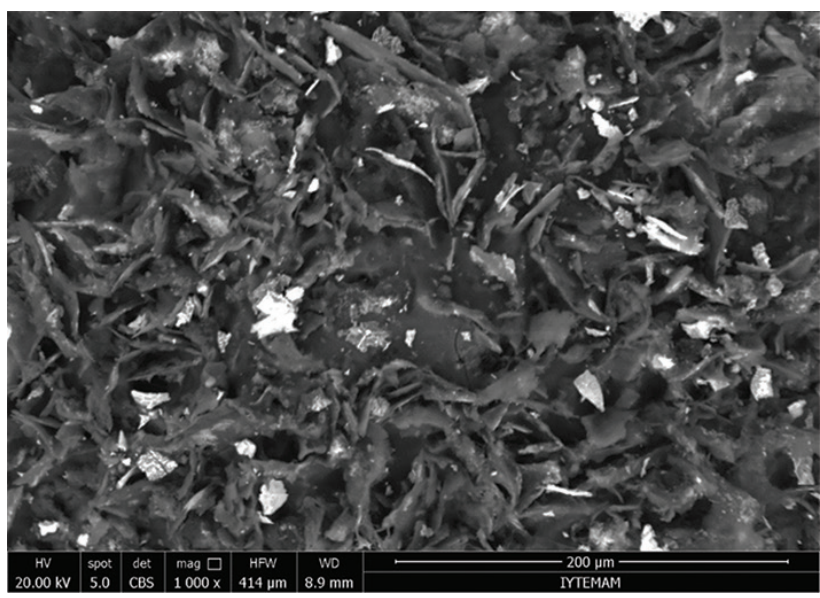

Figure 4: Scanning electron microscopy (SEM) images of FeNP synthesized by ASP.
FeNP $_{\mathrm{A}}[30,38,39]$. The XRD pattern of $\mathrm{FeNP}_{\mathrm{A}}$ were shown in Figure 7. The $2 \theta$ peaks at $18.106^{\circ}, 35.4^{\circ}$ and $40.48^{\circ}$ were attributed to crystal planes at (111), (220) and (311) respectively. The position and the relative intensity of the diffraction peaks match well with the standard XRD data for iron oxide nanoparticles (JCPDS file No. 19-0629) [3,30]. Finally, zeta potential analysis was carried out to prove the stability of $\mathrm{FeNP}_{\mathrm{A}}$

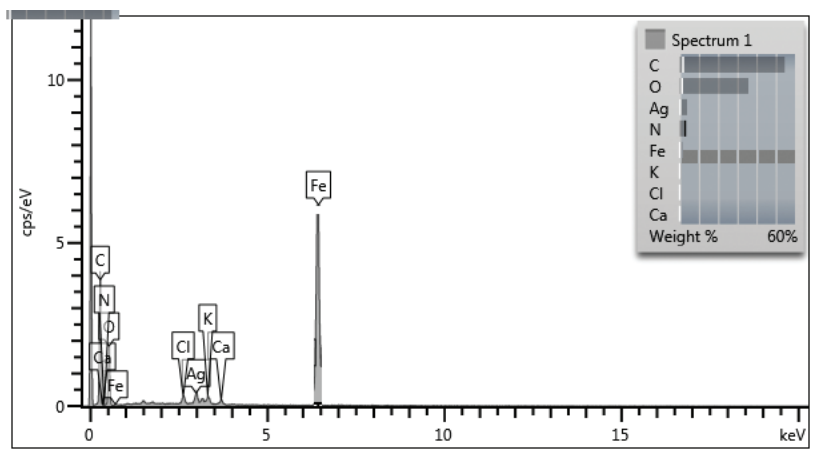

Figure 5: EDX spectrum of synthesized FeNP $\mathrm{A}_{\mathrm{A}}$ using $A S P$.

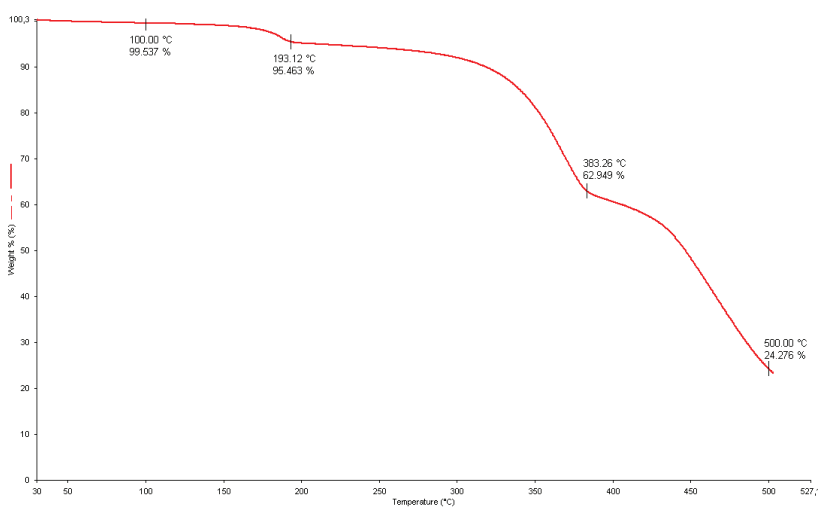

Figure 6: TGA analysis of synthesized $\mathrm{FeNP}_{\mathrm{A}}$ using $A S P$.

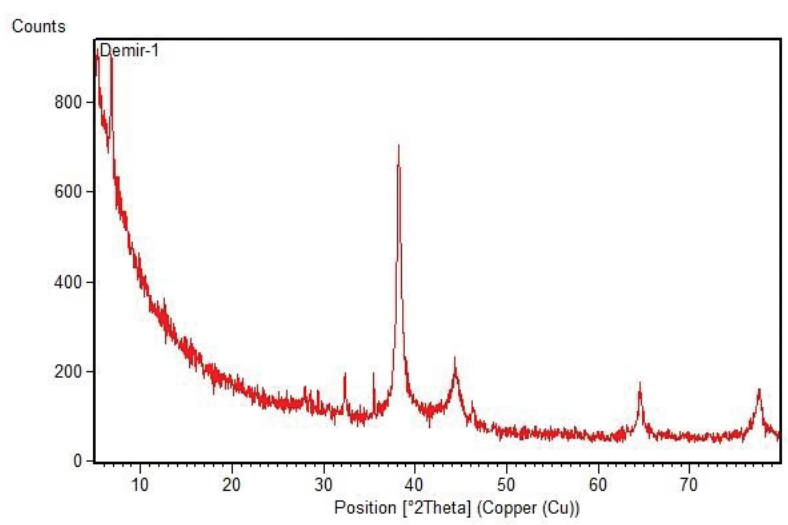

Figure 7: X-ray diffraction (XRD) patterns of the $\mathrm{FeNP}_{\mathrm{A}}$ synthesized by $A S P$. 
(Figure 8) The value $(-21.2 \mathrm{mV})$ guides the stability [40,41]. ABTS+, DPPH and $\mathrm{H}_{2} \mathrm{O}_{2}$ scavenging activities were performed for both ASP and FeNP ${ }_{\mathrm{A}}$. According to results $\mathrm{FeNP}_{\mathrm{A}}$ was more active than ASP by DPPH and ABTS ${ }^{+}$ methods. On the other hand results of $\mathrm{H}_{2} \mathrm{O}_{2}$ scavenging assay showed that $A S P$ was more active than $\mathrm{FeNP}_{\mathrm{A}}$ (Table 1). Mostly the FeNP $\mathrm{A}_{\mathrm{A}}$ showed more activity than ASP which gave rise to thought that FeNP s could used in many diseases caused by oxidative stress.

\subsection{Cytotoxicity of FeNP $\mathrm{A}_{\mathrm{A}}$ and $A S P$}

Breast cancer models MCF-7 and MDA-MB-231 and melanoma cancer models MeWo and CHL- 1 and fibroblast cell models WI-38 and HEL 299 (control cell models) were treated with $\mathrm{FeNP}_{\mathrm{A}}$ and $A S P 72 \mathrm{~h}$ to analyze the cytotoxic effects. The $\mathrm{IC}_{50}$ values of $\mathrm{FeNP}_{\mathrm{A}}$ were determined respectively as $139.40 \mu \mathrm{g} / \mathrm{mL}, 47.00 \mu \mathrm{g} / \mathrm{mL}, 38.48 \mu \mathrm{g} / \mathrm{mL}$, $5.26 \mu \mathrm{g} / \mathrm{mL}, 179.12 \mu \mathrm{g} / \mathrm{mL}, 32.70 \mu \mathrm{g} / \mathrm{mL}$ and $A S P$ were 4,39 $\mathrm{mg} / \mathrm{mL}, 25,56 \mu \mathrm{g} / \mathrm{mL}, 74,18 \mu \mathrm{g} / \mathrm{mL}, 29,44 \mu \mathrm{g} / \mathrm{mL}$, $98,98 \mu \mathrm{g} / \mathrm{mL}$, and $146,10 \mu \mathrm{g} / \mathrm{mL}$, respectively (Table 4). FeNP $_{\mathrm{A}}$ were more cytotoxic than ASP in MCF-7, MeWo, CHL-1, and HEL 299 cells (>31-, >1.9-, >5-, and >4-fold change in IC $_{50}$ values, respectively). When nanoparticle cytotoxicity

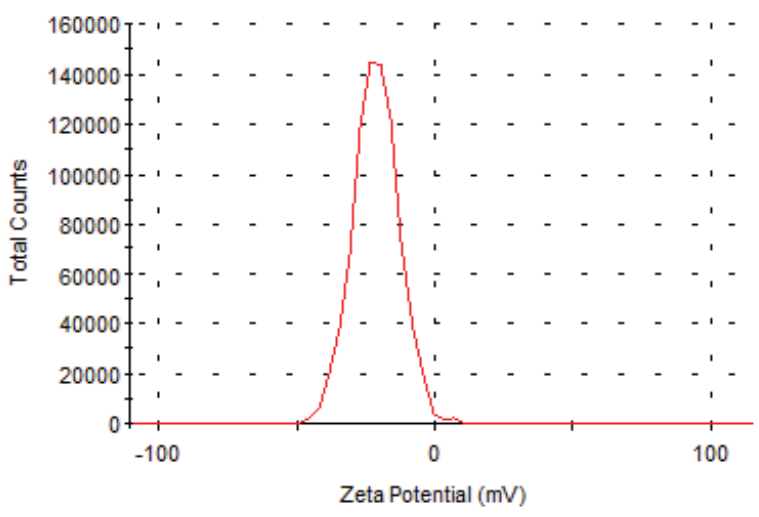

Figure 8: Zeta potential stabilization pattern analysis of synthesized $\mathrm{FeNP}_{\mathrm{A}}$ using $A S P$.

Table 4: $\quad \mathrm{IC}_{50}$ values of FeNP and $A S P$ in cell lines $(\mu \mathrm{g} / \mathrm{mL})$.

\begin{tabular}{lcccc}
\hline Cancer model & Cell lines & FeNP $_{\mathrm{A}}$ & \multicolumn{2}{c}{ Water extract } \\
\hline Breast & MCF-7 & 139.40 & 4390.00 & 31.49 \\
& MDA-MB-231 & 47.00 & 25.56 & -1.84 \\
Melanoma & MeWo & 38.48 & 74.18 & 1.93 \\
& CHL-1 & 5.26 & 29.44 & 5.60 \\
Control & WI-38 & 179.12 & 98.98 & -1.81 \\
& HEL 299 & 32.70 & 146.10 & 4.47 \\
\hline
\end{tabular}

was assessed, FeNP showed cytotoxicity in all cell lines. Aslanturk and Çelik used aqueous, diethylether, ethyl acetate and methanol extracts of $A$. aestivus. Aqueous extracts gave results $185.92 \mu \mathrm{g} / \mathrm{mL}$ at $24 \mathrm{~h}$ and $89.68 \mu \mathrm{g} / \mathrm{mL}$ for $72 \mathrm{~h}$ in MCF-7 cells (40). This difference in cytotoxicity is due to the use of different parts of the A. aestivus plant. In the present study, the upper parts of $A$. aestivus plant were used, however Aslanturk and Çelik were used ground tubers.

\subsection{Apoptotic effect of FeNP $\mathrm{A}_{\mathrm{A}}$ and $A S P$}

The apoptotic effect of $\mathrm{FeNP}_{\mathrm{A}} \mathrm{IC}_{50}$ values was determined and apoptosis was increased 2.21 fold in MCF-7 cells, 2.31 fold in MDA-MB-231, 1.29 fold in CHL-1 cells, 1.72 fold in MeWo cells, 19.85 fold in WI-38 cells and 3.71 fold in HEL 299 cells compared to the control group and ASP induced 4.93 fold, 1.21 fold, -1.03 fold, -2 fold, 1.55 fold, and 31.85 fold, respectively. FeNP $\mathrm{A}_{\mathrm{A}}$ had shown that mitochondria induce apoptosis through stress in MDA-MB-231, and cells MeWo ( $>1.9-$, and $>1.7-$ fold). ASP also induced apoptosis 2.23-fold in MCF-7 cells (Table 4). Aslanturk and Çelik were observed similar apoptosis for ASP. They had suggested that the apoptotic effect of $A$. aestivus plant extract was due to oxidative DNA damage resulting from proximal flavonoids present in the extract [42]. In the present study, results indicated that $\mathrm{FeNP}_{\mathrm{A}}$ was caused by oxidative DNA damage in apoptotic effect in MCF-7 and MDA-MB-231. However, it has been shown that $\mathrm{FeNP}_{\mathrm{A}}$ did not have apoptotic effects on melanoma cell lines, CHL-1 and MeWo it was referred to the fact that the antioxidant systems worked well in these cell lines so that no oxidative DNA damage could occur. Austin et al. had suggested that synthesized nanoparticles increase reactive oxygen species (ROS) levels, damage mitochondrial membranes, decrease ATP levels, and induce caspase-independent apoptosis in the nucleus loci of $\mathrm{p} 38$ MAPK and apoptosis inducing factor (AIF) proteins [43]. In the course of these findings, it was also been considering the apoptosis induction through the caspase independent pathway of FeNP $\mathrm{A}_{\mathrm{A}}$ synthesized in the present research.

\subsection{Effect of FeNP $\mathrm{A}_{\mathrm{A}}$ on gene expression}

$\mathrm{FeNP}_{\mathrm{A}}$ reduced 2 to 6 times of the 14 gene's expression and increased the expression of 5 genes 2 to 9 times in MCF-7 cells, reduced 7 gene expression by 2 to 9 fold, and increased 3 gene expressions by 2 to 10 fold in MDAMB-231 cells. ASP reduced the expression of 11 genes by 2 to 7 fold and increased the expression of 4 genes by 
2-11 fold compared to the control group in MCF-7 cells and increased expression of 4 genes by 2-9 fold in MDAMB-231 cells (Figure 9). In breast cancer cells, Keratin 5 (KRT5) gene expression was detected 4-fold increase and a 2-fold reduction in BIRC5, ESR1, IGF1 and TWIST1 gene expressions by $\mathrm{FeNP}_{\mathrm{A}}$ and $A S P$ treatment.

It had been shown that $\mathrm{FeNP}_{\mathrm{A}}$ treatment in breast cancer cell lines (MCF-7 and MDA-MB-231) affects the expression of many genes in mRNA. Kabos et al. observed a decrease in ESR1 protein and an increase in KRT5 protein in the combined administration of $17 \beta$-estradiol and antiestrogen tamoxifen or fulvestrant in MCF-7 cell line [44]. The same effect was found in ER+ tumors of neoadjuvant endocrine therapy patients and they suggested that it may be related to resistance to standard endocrine and chemotherapeutic agents. In the present study, $\mathrm{FeNP}_{\mathrm{A}}$ treatment showed an increase in KRT5 expression and a decrease in ESR1 expression in breast cancer cell lines. The similar response in two gene expressions without positive endocrine and/or chemotherapy was evaluated positively. Insulin-like growth factor (IGF) signaling was an important regulator of breast development and breast cancer. IGF1 and IGF2 were ligands of the IGF signaling pathway. It had been shown that IGF1 and IGF2 overexpression increase cell proliferation and tumor formation in mouse xenografts and do not alter resistance to chemotherapeutic drugs such as taxol. Overexpression
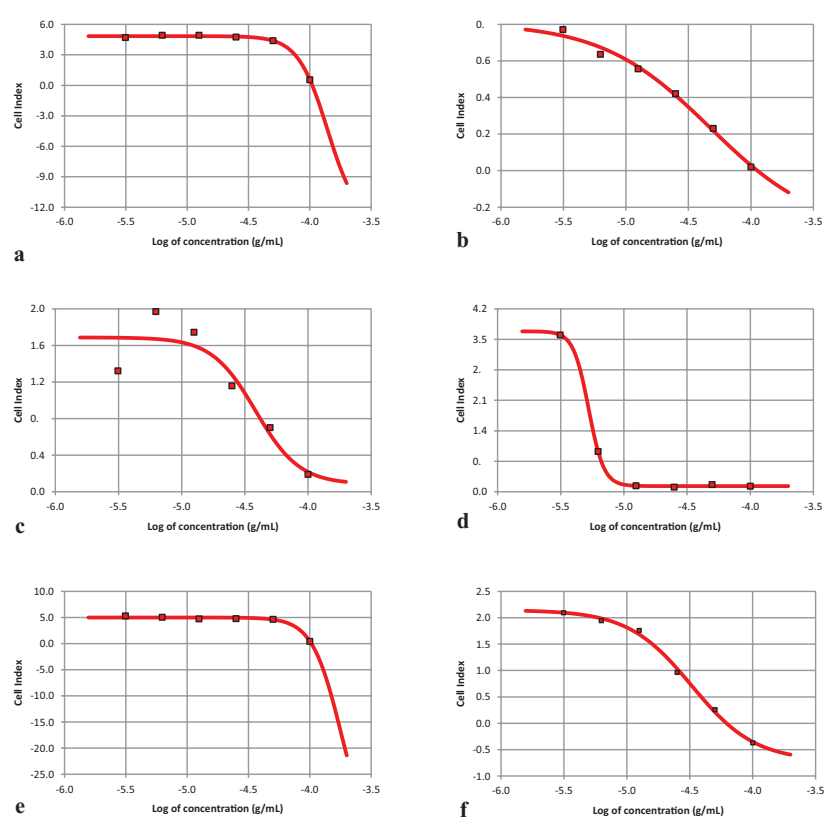

Figure 9: $I C_{50}$ value of FeNP $P_{A}$ were determined. (a) $I C_{50}$ was $139.40 \mu \mathrm{g} / \mathrm{mL}$ in MCF-7, (b) $47.00 \mu \mathrm{g} / \mathrm{mL}$ in MDA-MB-231, (c) in MeWo38.48 $\mu \mathrm{g} / \mathrm{mL}$, (d) $5.26 \mu \mathrm{g} / \mathrm{mL}$ in CHL-1, (e) $179.12 \mu \mathrm{g} / \mathrm{mL}$ in WI-38 and (f) $32.70 \mu \mathrm{g} / \mathrm{mL}$ in HEL 299. of IGF1 hd also been shown to cause overexpression of 9 genes in the IGF signaling pathway. It had been suggested that upregulation of these genes has stimulating effects on the IGF signaling pathway on global protein synthesis [45]. In this study, $\mathrm{FeNP}_{\mathrm{A}}$ administration reduced IGF1 expression about 3 fold in the MCF-7 cell line and about 9 fold in the MDA-MB-231 cell line. The present research supposed that the downregulation of IGF1 expression and the decrease of cell proliferation in $\mathrm{FeNP}_{\mathrm{A}}$ cytotoxicity were effective and and apoptosis was induced by a decrease in global protein synthesis (Figure 11).

In MeWo cells, FeNP A reduced the expression of 14 genes by 2 to 7 folds and increased the expression of 19 genes by 2 to 13 times and in CHL-1 cells, increased the expression of 17 genes by 2 to 8 times and decreased the expression of 7 genes by 3 to 9 times compared to the control group. ASP reduced the expression of 12 genes by 2 to 13 fold and increased the expression of 21 genes by 2-14 fold compared to the control group in CHL-1 cells and increased expression of 28 genes by 3-15 fold and reduced the expression of 8 genes by 2 to 11 fold in MeWo cells (Figure 10). BCL6, CXCL12, DNAJC15, RB1 and TPM1 gene expressions were increased in melanoma cancer cell. Bai et al. demonstrated that overexpression of BCL6 induces apoptosis by downregulation of BCL2 and BCL-XL in the diffuse large B cell lymphoma [46]. In CHL-1 and MeWo cell lines, $\mathrm{FeNP}_{\mathrm{A}}$ and $A S P$ treatment had been shown to increase BCL6 gene expression and $\mathrm{FeNP}_{\mathrm{A}}$ and $A S P$ administration in apoptosis induction has been assessed as providing BCL2 and BCL-XL suppression (Figure 12).
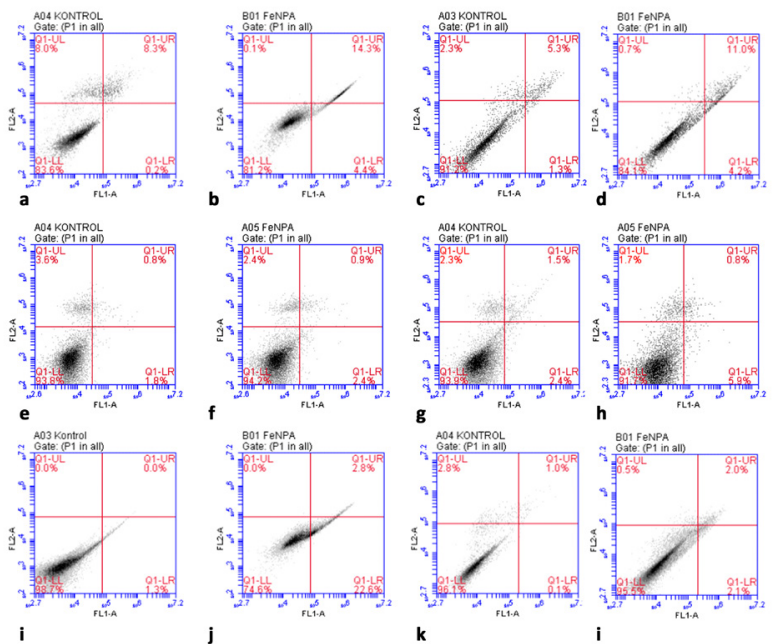

Figure 10: Apoptotic effect of FeNP ${ }_{A}$. Apoptosis was increased (b) 2.21 fold in MCF-7 cells, (d) 2.31 fold in MDA-MB-231, (f) 1.29 fold in CHL-1 cells, (h) 1.72 fold in MeWo cells, (j) 19.85 fold in WI-38 cells and (l) 3.71 fold in HEL 299 cells compared to the control group (a, c, e, g, $i$ and $k$ are untreated control groups of the cell lines, respectively). 


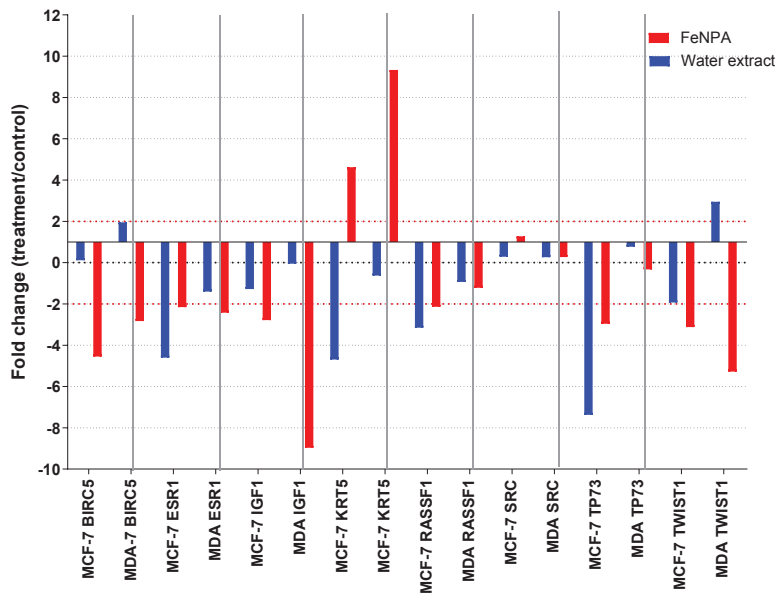

Figure 11: Effect of $\mathrm{FeNP}_{\mathrm{A}}$ and $A S P$ on gene expression in breast cancer model.

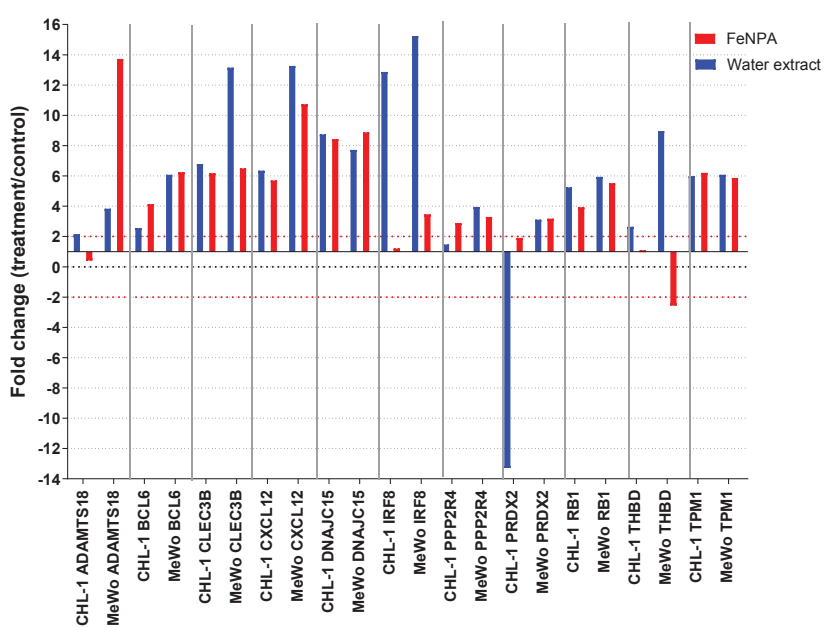

Figure 12: Effect of $\mathrm{FeNP}_{\mathrm{A}}$ and $A S P$ on gene expression in melanoma model

\section{Conclusion}

This is the first report on the antioxidant activity, cytotoxic activity and characterization of iron oxide nanoparticles synthesized from the aerial part of A. aestivus. Iron oxide nanoparticles were characterized by UV-visible, FT-IR, TEM, SEM/EDX, TGA, XRD and Zeta potential characterization methods. Biological activities of the extract and nanoparticles were compared. FeNP showed higher antioxidant and cytotoxic activities than ASP. FeNP $\mathrm{A}_{\mathrm{A}}$ was highly effective in breast cancer and melanoma cell lines, induced apoptosis and altered gene expression regulation that is important for prognosis. It was suggested that gene expressions regulated by $\mathrm{FeNP}_{\mathrm{A}}$ should be evaluated in further in vivo studies.
Acknowledgements: This research was supported by TUBITAK (project number SBAG-114S730). We are thankful to FABAL (Ege University, Faculty of Pharmacy Pharmaceutical Sciences Research Centre) and Izmir Institute of Technology, Center for Materials Research.

Conflict of interest: The authors of this work declare that they have no conflict of interest.

\section{References}

[1] Roco M.C., Nanotechnology: convergence with modern biology and medicine. Curr. Opin. Biotechnol., 2003, 14(3), 337-346.

[2] Zhang L., Gu F.X., Chan J.M., Wang A.Z., Langer R.S., Farokhzad O.C., Nanoparticles in Medicine: Therapeutic Applications and Developments. Clin. Pharmacol. Ther., 2008, 83(5), 761-769.

[3] Jagathesan G., Rajiv P., Biosynthesis and characterization of iron oxide nanoparticles using Eichhornia crassipes leaf extract and assessing their antibacterial activity. Biocatal. Agric. Biotechnol., 2018, 13, 90-94.

[4] Wang T., Jin X., Chen Z., Megharaj M., Naidu R., Green synthesis of Fe nanoparticles using eucalyptus leaf extracts for treatment of eutrophic wastewater. Sci. Total Environ., 2014, 466-467, 210-213.

[5] Ebrahiminezhad A., Hoseinabadi A.Z., Berenjian A., Ghasemi Y., Green synthesis and characterization of zero valent iron nanoparticles using stinging nettle (Urtica dioica) leaf extract. Green Process. Synth., 2017, 6, 469-475.

[6] Nagajyothi P.C., Pandurangan M., Kim D.H., Sreekanth T.V.M., Shim J., Green Synthesis of Iron Oxide Nanoparticles and Their Catalytic and In Vitro Anticancer Activities. J. Clust. Sci., 2017, 28, 245-257.

[7] Devi H.S., Boda M.A., Shah M.A., Parveen S., Wani A.H., Green synthesis of iron oxide nanoparticles using Platanus orientalis leaf extract for antifungal activity. Green Process. Synth., 2019, $8(1), 38-45$.

[8] Khan M.I., Mohammad A., Patil G., Naqvi S.A., Chauhan L.K., Ahmad I., Induction of ROS, mithocondrial damage and autophagy in lung epithelial cancer cells by iron oxide nanoparticles. Biomaterials, 2012, 33(5), 1477-1488.

[9] Fafal T., Taştan P., Tüzün Sümer B., Ozyazıcı M., Synthesis, characterization and studies on antioxidant activity of silver nanoparticles using Asphodelus aestivus Brot. aerial part extract. South African J. Bot., 2017, 112, 346-353.

[10] Matthews V., Asphodelus L., in Davis O.H. (Ed.), Flora of Turkey and the East Aegean Islands. Edinburgh, 1984, 85.

[11] Ali I., Wani W.A., Saleem K., Hseih M.-F., Design and synthesis of thalidomide based dithiocarbamate Cu (II), Ni (II) and Ru (III) complexes as anticancer agents. Polyhedron, 2013, 56, 134-143. 
[12] Ali I., Haque A., Saleem K., Hseih M.F., Curcumin-I knowevenangel's condasates and their Schiff's bases as anticancer agents: Synthesis, pharmacological and simulation studies. Biorgan. Med. Chem., 2013, 21, 3808-3820.

[13] Saleem K., Wani W.A., Haque A., Lone M.N., Hsieh M.F., Jairajpuri M.A., et al., Synthesis, DNA binding, hemolysis assays and anticancer studies of copper (II), nickel (II) and iron (III) complexes of a pyrazline based ligand. Future Med. Chem., 2013, 5(2), 135-146.

[14] Ali I., Nano Anti-cancer drugs: Pros and Cons future perspectives. Curr. Can. Drug Targets, 2011, 11, 131-134.

[15] Ali I., Saleem K., Wesselinova D., Haque A., Synthesis, DNA binding, hemolytic and anti-cancer assays of curcumin I-based ligands and their ruthenium (III), complexes. Med. Chem. Res., 2013, 22, 1386-1398.

[16] Basheer A.A., Chemical chiral pollution: Impact on the society and science and need of the regulations in the $21^{\text {st }}$ century. Chirality, 2018, 30, 402-406.

[17] Ali I., Wani A.W., Haque A., Saleem K., Glutamic acid and its derivates: candidates for ratonal design of anticancer drugs. Future Med. Chem., 2013, 5(8), 961-978.

[18] Harbeck N., Gnant M., Breast cancer. Lancet, 2017, 389, 1134-1150.

[19] Ali I., Wani W.A., Khan A., Haque A., Ahmad A., Saleem K., et al., Synthesis and synergistic antifungal activities of a pyrazoline based ligand and copper (II) and nickel (II) complexes with conventional antifungals. Microb. Pathog., 2012, 53, 66-73.

[20] Ali I., Wani W.A., Saleem K., Haque A., Thalidomide: A Banned Drug Resurged into future anticancer drug. Current Drug Ther., 2012, 7, 13-23.

[21] Ali I., Lone M.N., Al-Othman Z.A., Sanagi M.M., Heterocyclic scaffolds: cenrality in anticancer drug development. Curr. Drug Target, 2015, 16(7), 711-734.

[22] Ali I., Lone M.N., Alothman Z.A., Alwarthan A., Insights into the pharmacology of new heterocycles embedded with oxopyrrolidine rings: DNA binding, molecular docking and anticancer studies. J. Mol. Liq., 2017, 234, 391-402.

[23] Ali I., Wani W.A., Saleem K., Hsieh M-F., Anticancer metallodrugs of glutamic acid sulphonamides: in silico. DNA binding, hemolysis and anticancer studies. RSC Adv., 2014, 4, 29629.

[24] Ali I., Mukhtar S.D., Hsieh M.F., Alothman Z.A., Alwarthan A., Facile sytnhesis of indole heterocyclic compounds based micellar nano anticancer drugs. RSC Adv., 2018, 8, 37905.

[25] Subik K., Lee J.F., Baxter L., Strzepek T., Costello D., Crowley P., et al., The Expression Patterns of ER, PR, HER2, CK5/6, EGFR, $\mathrm{Ki}-67$ and AR by Immunohistochemical Analysis in Breast Cancer Cell Lines. Breast Cancer-Auckland, 2010, 4, 35-41.

[26] Ribas A., Flaherty K.T., BRAF targeted therapy changes the treatment paradigm in melanoma. Nat. Rev. Clin. Oncol., 2011, 8(7), 426-433.
[27] Ali I., Haque A., Wani W.A., Saleem K., Zaabi M.A., Analyses of anticancer drugs by capillary electrophoresis: a review. Biomed. Chramatogr., 2013, 27, 1296-1311.

[28] Ali I., Lone M.N., Aboul-enein H.Y., Imidazoles as potential anticancer agents. Med. Chem. Comm., 2017, 8, 1742.

[29] Arokiyaraj S., Saravanan M., Udaya Prakash N.K., Valan Arasu M., Vijayakumar B., Vincent S., Enhanced antibacterial activity of iron oxide magnetic nanoparticles treated with Argemone mexicana L. leaf extract: An in vitro study. Mater. Res. Bull., 2013, 48(9), 3323-3327.

[30] Awwad A.M., Salem N.M., A Green and Facile Approach for Synthesis of Magnetite Nanoparticles. Nanosci. Nanotechnol., 2012, 2(6), 208-213.

[31] Esmaeili M.A., Sonboli A., Antioxidant, free radical scavenging activities of Salvia brachyantha and its protective effect against oxidative cardiac cell injury. Food Chem. Toxicol., 2010, 48(3), 846-853.

[32] Patel A., Patel A., Patel A., Patel N.M., Determination of polyphenols and free radical scavenging activity of Tephrosia purpurea linn leaves (Leguminosae). Pharmacogn. Res., 2010, 2(3), 152-158.

[33] Devi H.S., Boda M.A., Shah M.A., Parveen S., Wani A.H., Green synthesis of iron oxide nanoparticles using Platanus orientalis leaf extract for antifungal activity. Green Process. Synth., 2019, 8(1), 38-45.

[34] Klačanová K., Fodran P., Šimon P., Rapta P., Boča R., Jorík V., et al., Formation of $\mathrm{Fe}(0)$-Nanoparticles via Reduction of $\mathrm{Fe}(\mathrm{II})$ Compounds by Amino Acids and Their Subsequent Oxidation to Iron Oxides. J. Chem., 2013, 2013, 1-10.

[35] Guo L., Huang Q., Li X., Yang S., Iron nanoparticles: Synthesis and applications in surface enhanced Raman scattering and electrocatalysis. Phys. Chem. Chem. Phys., 2001, 3, 1661-1665.

[36] Wei Y., Fang Z., Zheng L., Tsang E.P., Biosynthesized iron nanoparticles in aqueous extracts of Eichhornia crassipes and its mechanism in the hexavalent chromium removal. Appl. Surf. Sci., 2017, 399, 322-329.

[37] Balamurughan M.G., Mohanraj S., Kodhaiyolii S., National Conference on Green Engineering and Technologies for Sustainable Future, 2014, 201-204.

[38] Naseem T., Farrukh M.A., Antibacterial Activity of Green Synthesis of Iron Nanoparticles Using Lawsonia inermis and Gardenia jasminoides Leaves Extract. Hindawi Publ. Corp. J. Chem., 2015, 2015, 1-7.

[39] Alshehri A., Malik M.A., Khan Z., Al-Thabaiti S.A., Hasan N., Biofabrication of Fe nanoparticles in aqueous extract of Hibiscus sabdariffa with enhanced photocatalytic activities. Soc. Chem., 2017, 7, 25149-25159.

[40] Kumar R., Singh N., Pandey S.N., Potential of green synthesized zero-valent iron nanoparticles for remediation of leadcontaminated water. Int. J. Environ. Sci. Technol., 2015, 12, 3943-3950. 
[41] Zhang W., Elliott D.W., Applications of iron nanoparticles for ground water remediation. Remediat. J., 2006, 16, 7-21.

[42] Celik T., Aslantürk Ö.S., Investigation of antioxidant, cytotoxic and apoptotic activities of the extracts from tubers of Asphodelus aestivus Brot. African J. Pharm. Pharmacol., 2013, 7(11), 610-621.

[43] Austin L.A., Ahmad S., Kang B., Rommel R.K., Mahmouda M., Peek M.E., et al., Cytotoxic effects of cytoplasmic-targeted and nuclear-targeted gold and silver nanoparticles in HSC-3 cells - A mechanistic study. Toxicol. Vitr., 2015, 29, 694-705.

[44] Kabos P., Haughian J.M., Wang X., Dye W.W., Finlayson C., Elias A., et al., Cytokeratin 5 positive cells represent a steroid receptor negative and therapy resistant subpopulation in luminal breast cancers. Breast Cancer Res. Treat., 2011, 128(1), 45-55.

[45] Pacher M., Seewald M.J., Mikula M., Oehler S., Mogg M., Vinatzer U., et al., Impact of constitutive IGF1/IGF2 stimulation on the transcriptional program of human breast cancer cells. Carcinogenesis, 2007, 28(1), 49-59.

[46] Bai M., Agnantis N.J., Skyrlas A., Tsanou E., Kamina S., Galani V., et al., Increased Expression of the bcl6 and CD10 Proteins Is Associated with Increased Apoptosis and Proliferation in Diffuse Large B-Cell Lymphomas. Mod. Pathol., 2003, 16(5), 471-480. 